AL IBTIDA: JURNAL PENDIDIKAN GURU MI (2019) Vol 6 (2): 256-270

DOI: http://dx.doi.org/ 10.24235/al.ibtida.snj.v6i2.3793

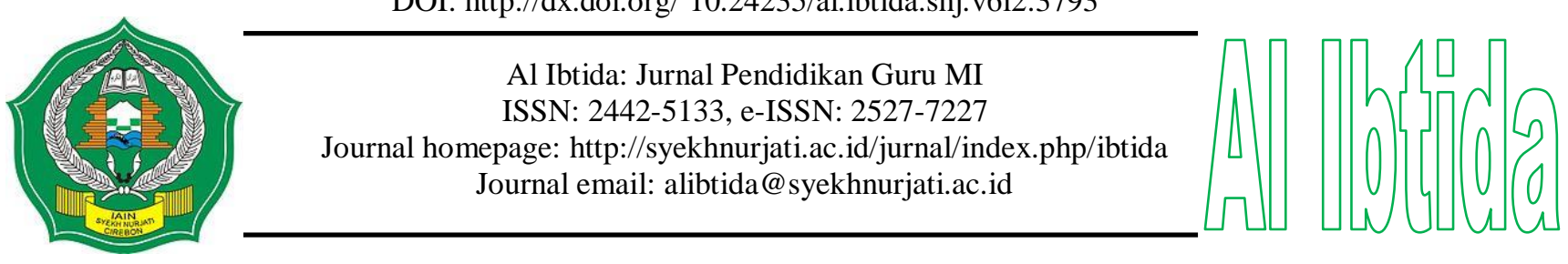

\title{
The Implementation of School Based Management in Madrasah Ibtidaiyah
}

\author{
Aceng Jaelani* \\ *Department of Madrasah Ibtidaiyah Teacher Education, Faculty of Tarbiyah and Teacher Training, \\ IAIN Syekh Nurjati Cirebon \\ Email: acengjaelani@syekhnurjati.ac.id \\ Moh. Masnun** \\ **Department of Madrasah Ibtidaiyah Teacher Education, Faculty of Tarbiyah and Teacher Training, \\ IAIN Syekh Nurjati Cirebon \\ Email: moh.masnun@syekhnurjati.ac.id
}

Received: January $07^{\text {th }}, 2019$. Accepted: September $20^{\text {th }}, 2019$. Published: October $29^{\text {th }}, 2019$.

\begin{abstract}
This study aims to determine the implementation of School Based Management (SBM) on student learning outcomes at Madrasah Ibtidaiyyah (MI) in Harjamukti District, Cirebon City. The research method adopted in this study was field research. Data collection is done through interviews, observation, and documentation. Data analysis techniques used in this qualitative research was inductive in nature, namely an analysis based on the obtained data. The steps taken were analyzing the data which has been collected; interpreting the data; drawing conclusions through way of thinking based on specific facts, where then directed to general conclusions. The results show that the implementation of SBM at MI in Harjamukti Cirebon District has been running quite effectively and efficiently. This can be seen from the support of all staff, SBM phasing, staff training, budget support and delegation of authority, high academic achievement of students, teachers mastery on materials and appropriate teaching procedures, efficient and effective use of facilities, teacher understanding of the characteristics of groups and individuals, a fun and interactive learning environment and the personality of teachers who can act as role models. Based on various aspects which have been arranged in school-based management, this has implications on improving student learning outcomes at Madrasah Ibtidaiyah in Harjamukti District, Cirebon City. Furthermore, this is evidenced in the school exam results.
\end{abstract}

Keywords: school based management, learning outcomes, madrasah ibtidaiyah

\begin{abstract}
Abstrak
Penelitian ini bertujuan untuk mengeksplorasi implementasi Manajemen Berbasis Sekolah (MBS) terhadap hasil belajar siswa di Madrasah Ibtidaiyah (MI) Se Kecamatan Harjamukti Kota Cirebon. Metode penelitian yang digunakan dalam penelitian ini adalah penelitian lapangan (field research). Pengumpulan data dilakukan dengan menggunakan wawancara, observasi, dan dokumentasi. Teknik analisis data dalam penelitian ini bersifat induktif, yaitu suatu analisis berdasarkan data yang diperoleh. Langkah yang dilakukan adalah Menelaah data yang berhasil
\end{abstract}


dikumpulkan, menafsirkan data, kemudian mengambil kesimpulan secara induktif, yaitu penarikan kesimpulan dengan cara berfikir berdasarkan faktafakta khusus, kemudian diarahkan kepada penarikan kesimpulan umum. Hasil penelitian menunjukkan bahwa penerapan MBS di MI se Kecamatan Harjamukti Cirebon sudah berjalan cukup efektif dan efesien, hal ini tercermin dari dukungan seluruh staf \& pelatihan staf, pentahapan MBS, dukungan anggaran dan pendelegasian wewenang, prestasi akademik siswa yang tinggi, penguasaan guru terhadap bahan dan prosedur mengajar yang tepat, pemanfaatan fasilitas secara efisien dan efektif, pemahaman guru tentang karakteristik kelompok dan perorangan, lingkungan belajar yang menyenangkan dan interaktif serta kepribadian guru yang bisa menjadi teladan. Berdasarkan berbagai aspek yang telah tersusun dalam manajemen berbasis sekolah, hal tersebut berimplikasi terhadap peningkatan hasil belajar siswa di Madrasah Ibtidaiyah se Kecamatan Harjamukti Kota Cirebon. Hal ini dibuktikan dalam hasil ujian sekolah.

Kata kunci: manajemen berbasis sekolah, hasil belajar, madrasah ibtidaiyah.

\section{INTRODUCTION}

One important element and can not be separated from humans is education. Education lasts a lifetime, ranging from the womb to adult and old. Education is obtained from various sources, both from parents, the community, and the environment through teaching methods or in other ways that have been recognized by the community. Being a human who has character and can live independently is one of the goals to be achieved from an educational process (Raharjo, 2010). In addition to forming character, developing the abilities and potential of students and forming a dignified national civilization so that a nation that is smart, faithful, devoted to God Almighty, noble, healthy, knowledgeable, competent, creative, independent, and becomes a democratic citizen and being responsible is also an important function of education. In general, humans need education in their lives to achieve a better life, this is called change. Change is a necessity in this life process. Through a change that is life will develop and dynamic. Therefore, education is the main helper for humans to establish this life.

Education gives humans progress in thinking that distinguishes humans from their predecessors in ancient times. Through education, science and technology have been developed. Along with the development of the times, all aspects of human life are also developing and even greater challenges. To face challenges in the future, it is necessary to strive to prepare quality human resources who are able and ready to compete at the national and global level. Efforts to prepare quality human resources through the world of quality education.

Efforts to improve quality education have been carried out since the past, both aspects of teacher qualifications, facilities, curriculum and procurement of books and 
learning tools. However, the implementation has not been maximized. This causes the low quality of education available at every level and unit of education, especially primary and secondary education and uneven implementation of education in cities and regions (Usman, 2014). Therefore, there must be a shift in the paradigm of education development from dependency to empowerment.

If described in more detail, the undeveloped quality of education can be caused by several factors, including 1) the input-output analysis approach that is not carried out consistently in relation to policies and the implementation of national education; 2) the approach to implementing national education is carried out centrally, so that in its implementation schools rely heavily on the bureaucracy; and 3) the lack of participation of parents and the community in the administration of education. During this time, the support of parents of students is limited to financial assistance, so the sense of parental ownership of the school is lacking, this has an impact on the lack of a sense of responsibility of the school in accounting for its educational outcomes to the community (Budimansyah, 2008).

Efforts to improve the quality of human resources also require support from the government. The government should increase commitment in order to improve the quality of education. On the other hand, local governments may not be able to work alone to achieve optimal, effective and efficient results in dealing with various educational problems, because there are still other parties with an interest in the education sector, such as: parents (community), schools (educational institutions), and other social institutions such as the business world or the industrial world. Therefore, it is very important the cooperation of the parties concerned to realize the principle of decentralization, especially in the field of education management.

Educational management strategies that promote collaboration between various parties are better known as the collaborative school, then this term is known as school based management (SBM). SBM provides broad autonomy at the school level within the framework of national education policy, which is a new paradigm that must be understood by related parties (Sutarto, Darmansyah, \& Warsono, 2012). This term first appeared in the United States when people began to question the relevance of education to the demands and development of local communities. Broad freedom between school principals and teachers in managing schools without ignoring government policies and authority is one of the concepts of implementing SBM.

A concept that illustrates the close collaboration between schools, communities and government with their respective responsibilities, based on a desire to provide independence to schools to be actively and dynamically involved in the framework of the process of 
improving the quality of education through the management of existing school resources. the concept of SBM as elaborated by Thoha (2012). The use of resources based on the school itself in the teaching or learning process is one of the characteristics of SBM (Ikhsan, 2010). Schools must be able to translate and capture the essence of macro education policies and understand their environmental conditions (strengths and weaknesses) to then be formulated into micro policies in the form of priority programs that must be implemented and evaluated by schools in accordance with their respective vision and mission.

Schools must plan, implement and evaluate targets to be achieved for each period of time, then determine quality targets for the following year. Thus, schools can be independent but still within the framework of national policy references, and be responsible (have accountability) for the learning needs of students and the community. Through the implementation of SBM which is applied by schools or madrasas, it is then linked to achievements made by students of each madrasa. Does the application of school-based management implemented in the madrasas studied and located in the Harjamukti Subdistrict of Cirebon City have positive implications for the learning outcomes of their students. Some previous studies were only limited to examining the implementation of SBM in schools / madrasas, while in this study the researchers tried to find out how to implement SBM and find out whether there were positive implications of applying SBM to the learning outcomes of Madrasah Ibtidaiyah students in Harjamukti Subdistrict.

Based on the description above, the management of educational institutions plays an important role in realizing the success of student learning. Given the importance of student learning success that is one indicator of the high quality of education, researchers feel the need to examine the implementation of school-based management and its implications for student learning outcomes in Madrasah Ibtidaiyah in Harjamukti District. This study aims to explore the implementation of School Based Management (SBM) on student learning outcomes in Madrasah Ibtidaiyah (MI) in Harjamukti Subdistrict, Cirebon City.

\section{METHODS}

The type of research method used in this study is field research, namely research aimed at conducting in-depth studies of a social unit in such a way as to produce a wellorganized and complete picture of the unit (Andriantonis \& Fitrianis, 2018). This research is qualitative (Qualitative Research) namely research to analyze and describe phenomena, events, social activities, attitudes, beliefs, perceptions, thoughts of people both individually and in groups (Bachri, 2010). Therefore, this research hypothesis will not be made in this study. 
The author uses several methods that support and complement each other to collect data. The first method is the observation method. According to Arikunto (2010) observation is often interpreted as a narrow asset, which is paying attention to something using the eyes. This method is used to know firsthand about the process of implementing SBM in Madrasah Ibtidaiyah (MI) in Harjamukti Subdistrict. This method is also used to determine the geographical location of the school.

The second data collection method is the interview method. The interview is a rechecking tool or proof of information or information obtained previously (Sutopo, 2006). This method is used to obtain the completeness of information and data orally in the form of information directly from research subjects to obtain information relating to research objectives relating to the implementation of management of school components.

In addition to the method of observation and interviews, researchers use the documentation method. The documentation method is the collection of data obtained through documents. The documentation method is the process of collecting data through written evidence, such as archives and books about opinions, theories or laws related to research (Margono, 2007). This method is used to obtain data in the form of school conditions and the implementation of SBM on the management of school components consisting of curriculum management and teaching programs, financial and financial management, facilities and infrastructure management, school and community relations management and special services.

The data that has been collected is then processed and classified for further analysis to facilitate the reader in giving interpretation. In addition, this analysis can narrow and limit the findings to become data that is orderly, structured and more meaningful. The author uses inductive thinking to analyze data, namely by drawing conclusions based on facts specific to the general nature. Data analysis is the process of compiling and sorting data into patterns, categories, and basic units of description in order to obtain themes and formulate working hypotheses as suggested by the data (Lutfi, 2013). Based on this description, the steps in analyzing the data in this study are a) reviewing the data that was collected, namely data from observations, interviews and documentation; b) conduct data reduction, i.e. take data that can be processed further; c) compile data in units; d) Interpret the data, then draw conclusions in an inductive way, namely drawing conclusions by thinking based on specific facts, then directed to drawing general conclusions. 


\section{RESULTS AND DISCUSSION}

\section{The Implementation of School Based Management in Madrasah Ibtidaiyah}

Implementation of School Based Management aims to increase school independence through giving greater authority to manage school resources and encourage the participation of all interest groups. In addition, schools also foster and develop seven components of school management through a more effective school management process (Triwiyanto, 2013). The seven school components that must be managed properly are as follows:

a. Curriculum and Learning Management

Curriculum management and learning includes curriculum planning, implementation, and evaluation activities. The Department of National Education at the central level oversees the planning and development of the national curriculum. Therefore, at the school level the task is to realize and customize the curriculum that the center has planned through learning activities. In addition, the school also has the responsibility and authority to develop local load curriculum to meet the needs of the local community and environment.

Eighth Madrasah Ibtidaiyah (MI) in the District of Harjamukti which is the location of the research area include MI Al Wathoniyah, MI Al Madinatunnajah, MI Al Hidayah GUPPI, MI Salafiyatul Huda 2, MI Salafiyah, MI Darul Masholeh, MI Darul Ulum, and MI As Shofiyah. The Madrasah Ibtidaiyah uses the 2013 curriculum or national curriculum. Based on the data obtained from the school, some are accredited BAN-S / M West Java Province are accredited with the B+ value of MI Al Wathoniyah, accredited with B grade MI Darul Ulum and six others are accredited A (very good) are namely: MI Al Madinatunnajah, MI Al Hidayah GUPPI, MI Salafiyahtul Huda 2, MI Salafiyah, MI Darul Masholeh, and MI As Shofiyah.

To compensate for the weaknesses of developing a centralized curriculum, it is necessary to develop a local content curriculum so that students love and recognize their environment, and are willing and able to preserve and develop natural resources, social quality, and culture that support national development, regional development, and local development. so students learn about the cultural social environment. Therefore, the existence of a local content curriculum is expected that schools can develop certain educational programs that are appropriate to the circumstances and their environmental demands.

Of course with the local content carried by each school tailored to the needs. For example, MI Madinatunnajah, although it was only established in 2004, has been using the 2013 curriculum and is presenting local content that meets its needs. According to Hakim (2016), several components considered important in the implementation of SBM are 
curriculum management and teaching programs. Curriculum development and teaching programs have proven that the development of curriculum and teaching programs is needed especially for students, because each school and even the region has different educational needs in accordance with the vision and mission and goals of the school. They still follow the rules that have been made by the government, keep using government policies and curriculum, it's just that they develop it by adjusting their individual needs.

b. Learner Management

Student management aims to regulate various activities in the student field so that learning activities in schools can run smoothly, orderly and regularly, and achieve the goals of school education. In order to achieve these goals, the student management field must pay attention to 3 main tasks, namely the admission of new students, learning progress activities, as well as guidance and coaching discipline.

Student management in MI Harjamukti sub-district is good. There are several MIs that have a large number of students such as MI Ash Shofiyah with 463 students and MI Salafiyah with 471 students. MI Salafiyah became MI with the highest number of students while MI Madinatunnajah became MI with the fewest students namely 121 students in the 2018/2019 school year. With a number of students above 200 students per school, MI in Harjamukti sub-district has had good student management.

c. Educators and Education Personnel Management

Staff development and development functions as the management of personnel that is absolutely necessary, to improve, maintain and improve teacher performance. Guidance and employee development activities in the management of educational staff in Madrasah Ibtidaiyah in Harjamukti Subdistrict in the research conducted, followed by teachers conducted routinely every month with meetings from the Department, guidance or information from the department delivered to schools how the results of the meeting. For development activities involving teachers to attend technical guidance for example following the technical guidance of 2013 curriculum.

One effort to support the implementation of SBM is the support of the government not to limit teacher creativity (Syahruddin, Ernawati, \& Ede, 2013). Through independent learning, workshops, further studies, and discussion groups, it is hoped that it can support teachers to carry out professional development. This relates to one effective strategy to improve the quality of human resources, including through the professional development of teachers. As for some of the efforts in teacher professional development including increasing the information technologi (IT) skills of teachers in developing teaching materials. Teachers 
can hone IT skills academically or non-academically through effective potential development activities.

d. Facilities and Infrastructure Management

Infrastructure facilities at Madrasah Ibtidaiyah in Harjamukti Subdistrict in the research conducted, have adequate infrastructure facilities among representative class rooms and rooms for other activities already exist. Overall there is no shortage of classrooms for implementing learning. Even in some MIs that have a large number of students, there are supporting facilities and infrastructure such as multipurpose buildings, school canteens, school cooperatives, UKS rooms, even BP's service rooms and school grounds.

A clean, neat, beautiful school and pleasant conditions for both teachers and students in the school are created through good management of facilities and infrastructure. In addition, it is expected that the availability of learning tools or facilities that are quantitative, qualitative, and relevant to the needs and can be used optimally for the education and teaching process, both by the teacher as a teacher and students as students.

e. Financing Management

Planning activities in the management of finance and financing $\mathrm{MI} \mathrm{Al}$ Madinatunnajah with more and more students, the income of funds is also increasing even though their needs are increasingly being designed in the form of a budget plan. The activities carried out in financial and financial management in MI Harjamukti sub-district in 2018 are managed in accordance with the budget plan. The headmaster gives additional tasks to teachers in the accountability of the available funds so that the task of managing money can be equitable and the principal does not hold any financial resources at the school. Evaluating activities in financial management and financing in MI throughout Harjamukti in 2018 is carried out every 3 months to make an accountability report so that the accountability report can be monitored and the financial application to what extent including the allocation of expenditures which need to be prioritized and which ones not yet.

Susilawaty, Harun, \& Khairuddin (2012) explained that the implementation or utilization of the financing budget begins with a series of inspection and approval activities to ensure that the budgeted funds are used according to plan, allocation of tax payments, and utilizing available resources. In addition, funds are not spent on activities that are not approved or given to the recipient without approval. The results of the needs analysis are logically classified into staff groups, curriculum materials, goods, services, building maintenance, and so on. 
f. School Relations with Community Management

School relationships with the community are in fact a very powerful means of building and developing the personal growth of learners in the school. Schools and communities have a very close relationship in achieving school goals or education effectively and efficiently. Eighth MI in the District of Harjamukti which is the research area include MI Al Wathoniyah, MI Al Madinatunnajah, MI Al Hidayah GUPPI, MI Salafiyatul Huda 2, MI Salafiyah, MI Darul Masholeh, MI Darul Ulum, and MI As Shofiyah implemented the program by applying the principles of relevance, flexibility, participation, comprehensive and institutional. Decisions to attract or withdraw funding from the community are agreed upon by the school, committee and education / foundation organizers.

The role of school committees in the context of public relations, acting as advisory agency, supporting agency, controling agency and mediating agency. Thus the school committee addresses both sides of the community to the school or vice versa, the school to the community. The key to the success of the madrasah in the management of public relations to the community is communication.

Mexico and Canada involve parents of students in school decision-making and management as a prerequisite for implementing MBS. In Iran the past few years have done similar things. Students' parents work with the school to contribute creative ideas to school programs in an effort to make MBS successful in school (Moradi, Beidokhti, \& Fathi, 2016).

g. Special Services Management

Special services Management include library management, health and school safety. Management of these components is an important part of effective and efficient SBM. In terms of the results of the implementation of the implementation of SBM in MI throughout the Harjamukti District of Cirebon it has run quite effectively and efficiently, this can be seen by the positive response and staff training, phasing in SBM, positive response to the budget and its use, the exercise of authority, high academic achievement of students, teacher mastery of teaching materials and procedures that are appropriate, efficient and effective use of facilities, good teacher understanding of the characteristics of groups and individual students, the creation of creative dialogue and a pleasant learning environment and teacher personality (exemplary).

\section{Implications of School Based Management Implementation to Improve Students' Learning Outcomes}

School Based Management also aims to increase effectiveness and efficiency. Effective means the management and use of all inputs in the form of non-money (the 
number and type of books, equipment, class organizing, methodologies, learning strategies, etc.) associated with the results achieved (output-outcome). With SBM every child will get quality education services at the school in question.

Increased school autonomy, flexibility and increased participation in the administration of schools, both the participation of school residents and the surrounding community through school committee representatives is the meaning of school-based management. That is, if school-based management wants to be successful, schools must increase partners, both from within and from outside the school. Partnerships in schools include, among others, principals with teachers, teachers with teachers, teachers with students, students with students, and so on. School partnerships with surrounding communities include, among others: principals with school committees, teachers with parents of students, principals with heads of district / city education offices, and so on.

Based on various aspects that have been arranged in school-based management certainly has implications with an increase in student learning outcomes in Madrasah Ibtidaiyah in Harjamukti Sub-District, Cirebon City. This is evidenced in the results of school exams. Not only that with the implementation of School Based Management (SBM) in Madrasah Ibtidaiyah (MI) in Harjamukti Sub-District, Cirebon City, many have reaped a myriad of achievements both academic or academic nom at various levels of the region. The above statement can be proven by the data obtained during the following research:

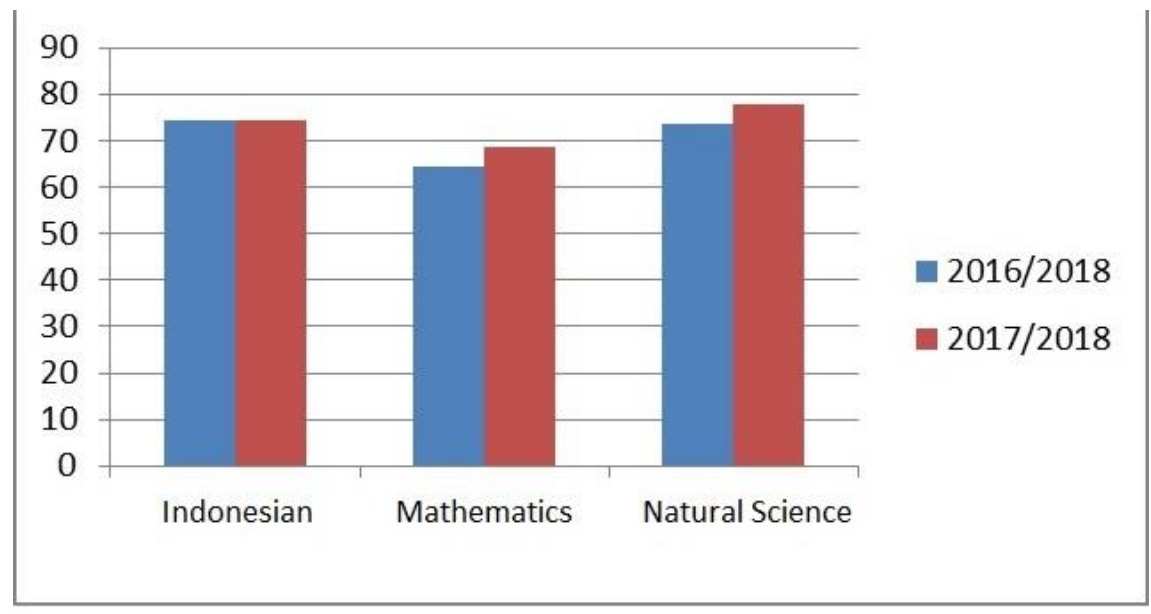

Graphic 1. Statistical Data on Average National Exam Grades Based on Subjects MI around Harjamukti Sub-District

The graphic 1 above showed an increase in the average results of several MI exams in Harjamukti Sub-District, Cirebon City from 2016/2017 to 2017/2018. From the results of the study obtained data that the value of the National Examination (UN) for Indonesian subjects increased from 74.33 to 74.42 . An increase in value of 0.9. Whereas in Mathematics there was an increase of 3, 92. In the 2016/2017 school year the average value of Mathematics for all MIs 
was 64.6 and then increased in the $2017 / 2018$ school year to 68.52 . For natural science subjects an increase of 4.20 from the previous year which only got a value of 73.74 then increased to 77 , 91.

Judging from the increase in these numbers, in general there is an increase in the value of each subject from the previous year. Although when viewed from each school there is an increase and decrease in the value of each school, but when viewed from the overall value per subject for all MIs throughout Harjamukti Subdistrict, there is an increase in learning outcomes in MI Harjamukti Subdistrict.

In addition to increasing the value of MI National Examination Students in Harjamukti Subdistrict, the average National Examination score of MI Harjamukti students also experienced an increase. Following are the data obtained during the study regarding the improvement in the average results of MI students in the UN in the District of Harjamukti.

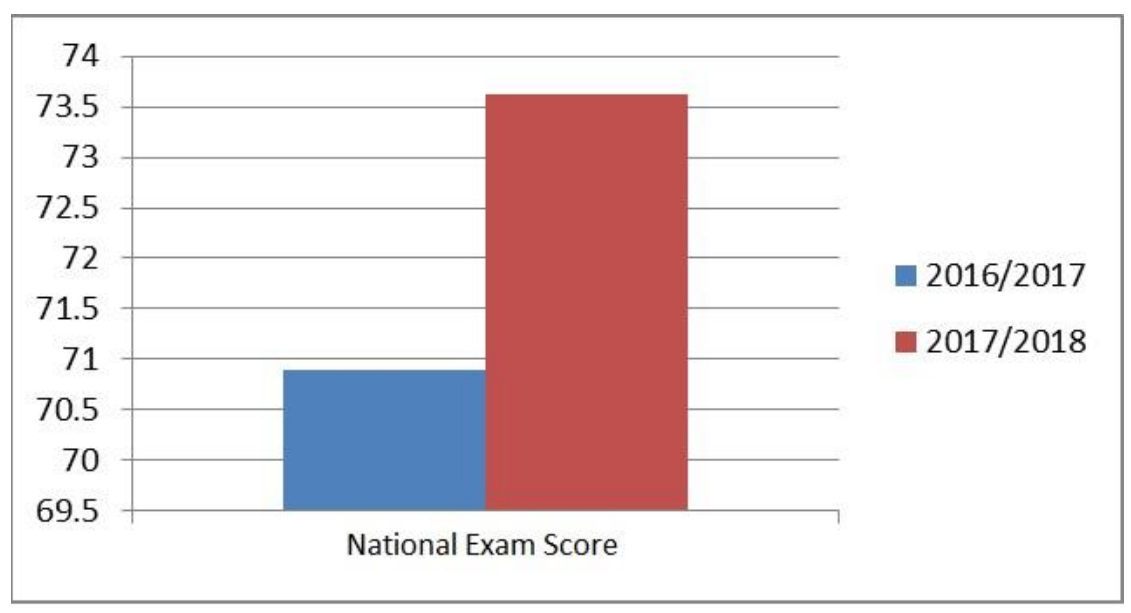

Graphic 2. Statistical data on average UN scores of several MIs in Harjamukti Subdistrict

From graphic 2 above, it can be seen that there is an increase in the average score of National Examination for MI students in Harjamukti Subdistrict. In 2016/2017 the average national exam scores of MI students in Harjamukti Sub-district were 70.89. In the 2017/2018 school year, there was an increase in the average score of MI National Exam results in Harjamukti Sub-district to 73.62. An increase in value of 2.73 .

This shows that when SBM goes well in school, the learning outcomes of students will increase. This is evident from the observations of researchers in the form of statistics on the average results of the National Examinations of several MIs in Harjamukti Sub-District, Cirebon City. Judging from the average results of the National Examination both gem lessons and the average results of the National Examination as a whole there is an increase in the National Examination results of MI students in Harjamukti District from the previous year.

The increase in National Examination results is even very significant in some schools such as MI Darul Masholeh which increased by 25.57 from the initial value of 42.55 then rose to 
68.02. MI Darul Ulum increased by 12.67 from the initial value of 58.76 and then increased to 70.09. But indeed there was a decrease in the National Examination results also in several MIs in Harjamukti Subdistrict but the decrease was not too significant. The decline in learning outcomes is due to various factors that inhibit and often cause SBM to not run properly in the MI.

This increased achievement proves that School Based Management is able to improve student achievement. Hamid in Wijaya (2014) stated that the implementation of SBM would be able to boost student achievement. One of the reasons for the increase in student achievement is that schools are able to independently meet their needs and needs to make the quality of education increase. This is in accordance with the opinion of Usman (2014) which states that School Based Management (MBS) aims to empower or empower schools through giving authority, flexibility, and resources to improve school quality. Through the implementation of school-based management students have an increase in learning achievement and bring happiness and pride in the hearts of teachers to the achievements achieved by students and visible improvement in teacher professionalism (Sulaiman, Hasmiana, \& Asmaini, 2016). The same thing was also expressed by Ayeni \& Ibukun (2013) who explained that the application of school-based management can improve the quality of teaching and improve student learning outcomes in Nigerian secondary schools by optimizing and organizing resources, utilizing and managing learning facilities.

\section{Factors that are supporting and inhibiting the Implementation of School Based Management in Madrasah Ibtidaiyah}

a. Supporting Factors in the Implementation of School Based Management in Madrasah Ibtidaiyah

Factors supporting the implementation of SBM in Madrasah Ibtidaiyah in Harjamukti Sub-district, Cirebon City are greater authority or autonomy from the government to madrasas, socialization of improving the quality of education from the government, education budget assistance from both the government and the community (student guardians), the willingness of school residents to progress together, and school committee participation is increasingly active. As factors support the implementation of SBM in Madrasah Ibtidaiyah in Harjamukti Sub-District, Cirebon City include, first, authority owned by madrasah. This is in accordance with the opinion Usman (2014) which states that School Based Management aims to empower or empower schools through giving authority, flexibility, and resources to improve school quality. Thus, schools will gradually form high independence. With full authority of the school, it 
makes it easier for schools to create and control programs that will be implemented in schools to suit the needs of students themselves. School community involvement in decision making, then the school community will foster a greater sense of ownership coupled with a higher sense of responsibility (Sabil, 2014).

Second, optimal stake holder involvement. Optimal stakeholder involvement will greatly help the implementation of SBM in the school. This is consistent with the opinion Haryanto (2014) which states the role of schools in the context of SBM is as a driving force for school life. The role is the principal as an educator, manager, administrator, supervisor, leader, entrepreneur, motivator, and climator. Therefore optimal stakeholder involvement will be an excellent supporting factor. Third, clear information system, and fourth, continuing reward system.

b. Inhibiting Factors in the Implementation of School Based Management in Madrasah Ibtidaiyah

Based on an analysis of the aspects that influence the obstacles in the implementation of school management are 1) the limited facilities and infrastructure owned by each school; 2) the quality of human resources both educators and education personnel are still lacking in several MIs in Harjamukti District; 3) lack of coordination between foundations and school committees in several MIs in Harjamukti Sub-District, Cirebon City.

According to Tabrani (2013) problems faced by religious education units (Islam) include: first, funding in the administration of education is very minimal; second, the teaching and educational staff have not met the competency standards; third, facilities and infrastructure that are still of concern, because most are the result of community funding; fourth, not optimal in curriculum development, because of centralized policies. The achievement of optimal professionalism and accountability is a challenge in the implementation of SBM in the religious education unit (Islam), because almost throughout the founding of the Indonesian state, this institution lacked guidance from the government. Efforts that can be made to overcome these obstacles are by digging community support, improving community perspectives, socializing programs, empowering school committees and increasing school independence (Suditha, 2011).

\section{CONCLUSION}

Based on the results of research and discussion, it can be concluded that the implementation of school based management in MI throughout the Harjamukti District of Cirebon has been running quite effectively and efficiently, this can be seen from the support 
of all staff, phasing in SBM, staff training, budget support and delegation of authority, high academic achievement and non-academic students, the teacher masters appropriate teaching materials and procedures, uses facilities efficiently and effectively, the teacher's understanding of group and individual characteristics, a fun and interactive learning environment and the teacher's personality that can be a role model. Things that encourage the achievement of the implementation of school based management in Madrasah Ibtidaiyah in Harjamukti Sub-district of Cirebon City include (1) the authority possessed by madrasas, (2) optimal stakeholder involvement, (3) clear information systems, and (4) an ongoing reward system. Therefore, Madrasah Ibtidaiyah in Harjamukti Sub-district of Cirebon City can be used as role models in the application of school based management for other Madrasah Ibtidaiyah.

\section{REFERENCES}

Andriantoni, \& Fitrianis. (2018). Problematika Dan Solusi Implementasi Kurikulum 2013 (Studi Kasus Implementasi Kurikulum 2013 Di SMPN 31 Padang). Jurnal Tarbawiy, 5(1), 111112.

Arikunto, S. (2010). Prosedur Penelitian Suatu Pendekatan Praktik. Jakarta: Rineka Cipta.

Ayeni, A. J., \& Ibukun, W. O. (2013). A Conceptual Model for School-Based Management Operation and Quality Assurance in Nigerian Secondary Schools. Journal of Education and Learning, 2(2), 36-43.

Bachri, B. (2010). Meyakinkan Validitas Data Melalui Triangulasi pada Penelitian Kualitatif. Jurnal Teknologi Pendidikan, 10(1), 46-62.

Budimansyah. (2008). Peningkatan Mutu Pendidikan Melalui Penguatan Partisipasi Masyarakat. Jurnal Educationist, 2(1), 46-62.

Hakim, M. N. (2016). Implementasi Manajemen Berbasis Sekolah Dalam Mewujudkan Sekolah Islam Unggulan. Nidhomul Haq, 1(2), 104-114.

Hamid. (2013). Manajemen Berbasis Sekolah. Al-Khawarizmi, 1(1), 87-96.

Haryanto, L. d. (2014). Peran Kepala Sekolah dalam Penerapan Manajemen Berbasis. Jurnal Akuntabilitas Manajemen Pendidikan, 2(2), 174-187.

Ikhsan. (2010). Penerapan Manajemen Berbasis Sekolah SMK Negeri dan SMK Swasta SeKarasidenan Semarang. Jurnal Dinamika Pendidikan, 5(1), 1-19.

Lutfi, A. (2013). Metode Tahfidz Al-Qur'an (Studi Komparatif Metode Tahfidz Al-Qur'an di Pondok Pesantren Madrasah al-Hufadzh II Gedongan Ender, Pangenan Cirebon dengan Pondok Pesantren Tahfidz Qur'an Terpadu AlHikmah Bobos, Dukupuntang Cirebon). Holistik, 2(2), 159-173.

Margono, S. (2007). Metologi Penelitian Pendidikan Komponen MKDK. Jakarta : Pt. Rineka Cipta. 
Moradi, S., Beidokhti, A. A., \& Fathi, K. (2016). Comparative Comparison of Implementing School-Based Management in Developed Countries in the Historical Context: From Theory to Practice. International Education Studies, 9(9), 191-198.

Raharjo. (2010). Pendidikan Karakter Sebagai Upaya Menciptakan Akhlak Mulia. Jurnal Pendidikan dan Kebudayaan, 16(3), 229-238.

Sabil, H. (2014). Implementasi Manajemen Berbasis Sekolah (MBS). Jurnal Sainmatika, 8(1), 112.

Suditha. (2011). Studi Evaluasi Efektivitas Penerapan Manajemen Berbasis Sekolah (MBS) Pada SMP Saraswati 1 Tabanan. Jurnal Administrasi Pendidikan Indonesia, 2(2), 1-13.

Sulaiman, Hasmiana, \& Asmaini. (2016). Implementasi Manajemen Berbasis Sekolah (MBS) dalam Meningkatkan Profesionalisme Guru di SD Negeri 10 Banda Aceh. Jurnal Ilmiah Mahasiswa Pendidikan Guru Sekolah Dasar, 1(1), 31-39.

Susilawaty, Harun, C. Z., \& Khairuddin. (2012). Manajemen Berbasis Sekolah dalam Pengelolaan Pembiayaan Sekolah di SD Negeri 4 Kota Banda Aceh. Jurnal Administrasi Pendidikan, 1(2), 34-37.

Sutarto, M., Darmansyah, \& Warsono, S. (2012). Manajemen Berbasis Sekolah . The manager Review, 13(3), 343-355.

Sutopo, H. (2006). Metode Penelitian Kualitatif. Surakarta: UNS Press.

Syahruddin, Ernawati, E., \& Ede, M. N. (2013). Teachers' Pedagogical Competence in SchoolBased Management. Journal of Education and Learning, 7(4), 213-218.

Tabrani, Z. (2013). Kebijakan Pemerintah dalam Pengelolaan Satuan Pendidikan Keagamaan Islam (Tantangan Terhadap Implementasi Manajemen Berbasis Sekolah). Serambi Tarbawi, 1(2), 245-264.

Thoha. (2012). Pembelajaran Bahasa Arab Dengan Pendekatan Manajemen Berbasis Sekolah. Jurnal Okara, 6(1), 79-90.

Triwiyanto, T. (2013). Pemetaan Mutu Manajemen Berbasis Sekolah melalui Audit Manajemen Pendidikan. Manajemen Pendidikan, 24(2), 125-134.

Usman, A. (2014). Meningkatan Mutu Pendidikan Melalui Penerapan Manajemen Berbasis Sekolah. Jurnal Ilmiah Didaktika, 15(1), 13-31.

Wijaya, D. (2014). Model Balanced Scorecard Dalam Implementasi Manajemen Berbasis Sekolah (MBS). Jurnal Ilmiah Manajemen Bisnis, 14(1), 45-58. 